\title{
Copper levels in human mixed, nuclear brunescence, and posterior subcapsular cataract
}

\author{
M Balaji, K Sasikala, T Ravindran
}

\begin{abstract}
The study was undertaken to determine the copper content in different human cataractous lenses. The level of copper increased with increasing age in nuclear brunescence and mixed cataractous lens and a low amount of copper was observed in the posterior subcapsular cataractous lens with increasing age. Cataractous lenses of females have greater amounts of copper compared with males.

(Brf Ophthalmol 1992; 76: 668-669)
\end{abstract}

Metals in human fluids and tissues are of potential importance not only in medical investigation but also in everyday clinical practice. ' In recent times a role for trace elements in human nutrition has been identified and an involvement in different diseases. ${ }^{2}$

Most of the mineral elements previously regarded as physiologically inactive have now been found to participate in a variety of biological processes. Trace elements function primarily as catalysts in enzyme system in the cells. Of several trace elements, inorganic ions such as copper are essential virtually for all biochemical and physiological process in humans and they occur in minute amounts. ${ }^{3}$

The presence of trace elements such as copper in tissues was reported in the early part of century $^{4}$ and the role of copper in cataract formation has intrigued the biochemists and physicians for a long time.

Copper is essential for the activity of numerous enzymes such as cytochrome oxidase, superoxide dismutase, and uricase. ${ }^{5}$ Derangements in copper metabolism and resulting changes in its concentration within tissues and body fluids have been associated with pharmalogical states. ${ }^{6}$ The copper content of the human lens has been of particular interest because of its possible relation to cataractogenesis, ${ }^{7}$ and it is found in elevated levels in the state of cataract maturity. ${ }^{8}$

The present investigation was undertaken to determine the levels of copper in posterior subcapsular nuclear brunescence of the mixed lens of males and females in different age groups.

\section{Materials and methods}

This investigation was carried out on 200 patients admitted to the various eye hospitals in Coimbatore during January to November 1991. The age and sex of patients were recorded and cataractous lenses were categorised as nuclear brunescence, posterior subcapsular (PSC), and mixed cataracts, as described by Oxford classification system. ${ }^{9}$ The normal lenses were obtained from an eye bank located in Coimbatore and these were used as controls. The lenses were collected in glass containers, washed with Teepol, and rinsed with double distilled water to avoid contamination.

Each lens was oven dried and weighed separately. They were then digested in $3 \mathrm{ml}$ of a digestion mixture of concentrated nitric acid and perchloric acid in the ratio $3: 1$. The mixture was then evaporated to dryness and to the precipitate was added $10 \mathrm{mmol}$ nitric acid. The level of copper was estimated at $324.9 \mathrm{~nm}$ in an atomic absorption spectrophotometer. ${ }^{10}$ All the mean values were analysed by $t$ test to determine the significance.

\section{Results and discussion}

Increased levels of copper were observed in cataractous lenses compared with controls. The copper content was increased with increasing age but only in nuclear brunescence of the mixed cataractous lenses.

In females, cataractous lenses show higher levels of copper than males. The PSC cataractous lens (Table 1) showed a decrease in copper content at all ages with a mean value of 1.73 (SD $1.23) \mu \mathrm{g} / \mathrm{g}$ dry wt in males and a level of 1.93 (SD $1 \cdot 35) \mu \mathrm{g} / \mathrm{g}$ dry wt in females in the age range 4150 years. Gradually the copper content decreased as the age increased to 61-70 years with a mean value of 1.40 (SD 0.74) in males and 1.43 (SD $0 \cdot 82) \mu \mathrm{g} / \mathrm{g}$ in females. All the mean values of PSC were higher than control values. It was seen in the case of nuclear brunescence cataract lenses (Table 2) that there was a higher copper content with increasing age with a maximum mean value of $2 \cdot 11$ (SD 1.68) $\mu \mathrm{g} / \mathrm{g}$ in female lenses, and a maximum mean value of 2.00 (SD 1.50$) \mu \mathrm{g} / \mathrm{g}$ in males. In mixed cataract lenses (Table 3) an increase in copper content with age was also observed. Here also, the mean value was higher when compared with the control group. These results showed that copper content is higher in

Table 1 Data showing the copper concentration in lenses with posterior subcapsular cataract in thre age groups $(\mu g / g$ dry wt)

\begin{tabular}{|c|c|c|c|c|c|}
\hline Sex & Parameter & $\begin{array}{l}\text { No of } \\
\text { lenses } \\
\text { observed }\end{array}$ & $\begin{array}{l}\text { Age } \\
\text { group } \\
\text { (years) }\end{array}$ & $\begin{array}{l}\text { Copper } \\
\text { concentr } \\
\text { Mean }\end{array}$ & $\begin{array}{l}\text { ation } \\
S D\end{array}$ \\
\hline \multirow[t]{6}{*}{ Male } & Control & 50 & $41-50$ & $1 \cdot 32$ & $0 \cdot 70$ \\
\hline & & 50 & $51-60$ & 1.22 & 0.64 \\
\hline & & 50 & $61-70$ & $1 \cdot 20$ & 0.52 \\
\hline & Experimental & 100 & $41-50$ & 1.73 & $1 \cdot 23$ \\
\hline & & 100 & $51-60$ & 1.50 & 0.95 \\
\hline & & 100 & $61-70$ & $1 \cdot 40$ & 0.74 \\
\hline \multirow[t]{6}{*}{ Female } & Control & 50 & $41-50$ & 1.40 & 0.73 \\
\hline & & 50 & $51-60$ & $1 \cdot 32$ & 0.70 \\
\hline & & 50 & $61-70$ & $1 \cdot 23$ & 0.58 \\
\hline & Experimental & 100 & $41-50$ & 1.93 & $1 \cdot 35^{\star}$ \\
\hline & & 100 & $51-60$ & 1.54 & $1.05^{\star}$ \\
\hline & & 100 & $61-70$ & 1.43 & $0 \cdot 82^{\star}$ \\
\hline
\end{tabular}

*Values significant at $5 \%$ level 
Table 2 Data showing the copper concentration in lenses with nuclear brunescence cataract in three age groups ( $\mu \mathrm{g} / \mathrm{g}$ dry wt)

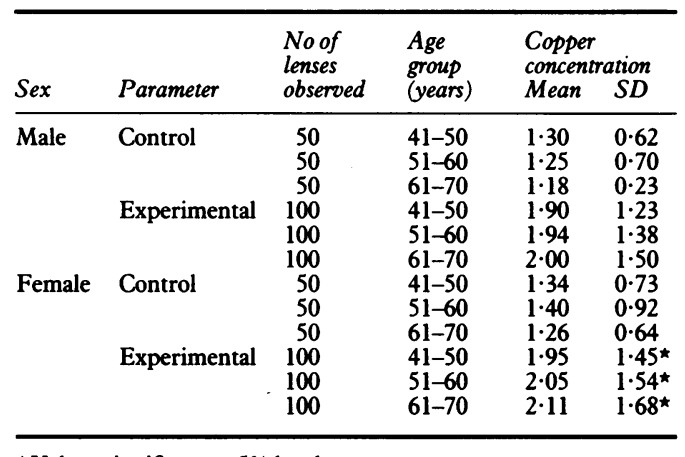

$\star$ Values significant at $5 \%$ level

the nuclear brunescence cataractous lenses than the mixed cataractous lenses as age increases. The reverse is noted in PSC cataractous lenses where there is an increased amount of copper in the lower age group. Females have larger amounts of copper than males.

In the present study it was concluded that in mixed cataractous lenses the copper concentration increases with the increase in age. This confirms the study of Nath et al. ${ }^{11}$ This increase was due to the inhibition of lactate dehydrogenase activity in the formation of cataract. The increase in copper content in senile lenses was also reported by Jain and Nath. ${ }^{12}{ }^{13}$ However, copper is important for various metalloenzymes such as cytochrome oxidase and aldolase, which are vital for the maintenance of cell growth.

A study of copper concentration of cataractous lenses in vertebrates reported no correlation between copper concentration and cataract. ${ }^{7}$

The nuclear portion of the lens has less copper ${ }^{14}$ but this present study deviates from this statement. The increasing concentration of copper in the nuclear cataract lenses has also been reported elsewhere, ${ }^{15} 16$ confirming the results of the present study. Shlopak ${ }^{13}$ stated that the copper concentration in the cataractous lenses decreases as age increases; this is associated with more metabolic activity of lenses, but again this is not seen in the present study. Marraini and Mangoli $^{17}$ observed that in the cortical type of cataract the main features are the alteration of water content resulting in hydration of tissue.

The presence of excess levels of copper in cataract may oxidise sulphydryl groups to disulphides followed by a reduction of copper which may generate $\mathrm{O}_{\overline{2}}$ radicals ${ }^{15}$; copper in higher concentrations can be toxic to cells. ${ }^{18}$

Copper ions, therefore, may be responsible for the damage to the lens capsule, thereby causing leakage of beta and gamma crystallins into the aqueous humour, and conversion to insoluble proteins during the process of cataractogenesis. ${ }^{19}$

In conclusion, the copper content increases with increasing age in nuclear brunescence and mixed cataractous lenses, and copper content
Table 3 Data showing the copper concentration in lenses with mixed cataract in three age groups ( $\mu g / g$ dry wt)

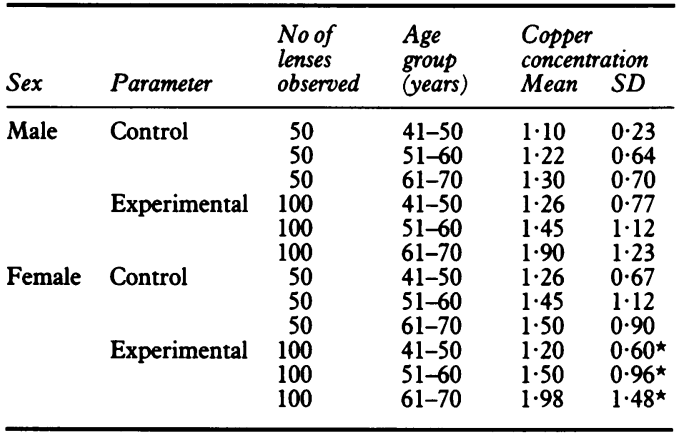

$\star$ Values significant at $5 \%$ level

and age are directly proportional to each other in these conditions. In the case of PSC cataract lenses the reverse is true.

Further investigation on the amount of trace elements present in cataract formation is needed.

The authors are indebted to Professor G Sundararajula, Head of the Department of Zoology, for giving valuable suggestions and providing necessary laboratory facilities to carry out the work. Our thanks are due to various hospitals who supplied materials during the course of our study. M Balaji is grateful to CSIR for the award of a senior research fellowship.

1 Hundi KV, Maroit Gomiscek M, Gomiscek S. The determination of trace metals in human fluids and tissues, Part 3. Anal Chem Acta 1984; 157: 303-11.

2 Ulmer DD. Disturbances in trace element metabolism. In Harrisons principles of internal medicines, 10th ed. McGraw Hill: New York, 1977: 470-500.

3 Cooper J. Diseases of lens and vitreous: glaucoma and hypotony system of ophthalmology. Vol XI; Trans Ophthalmol Soc UK 1928; 340 .

4 Underwood EJ. Trace elements in human and animal nutrition. Academic: New York, 1977: 12-4.

5 Ulmer DD. Disturbances in trace element metabolism. In Harrisons principles of internal medicine, 11 th ed. McGraw Harrisons principles of internal

6 Martin NF, Kincaid MC, Jain S. Study of trace elements of cataract. CIBA Symp 1973; 79: 79-81.

7 Coo KS, Megahan MC. Cataractous lens. Curr Eye Res 1986; 5: 69-77.

8 Fong D, Etzel K, Lee P, Lam KW. Factors affecting ascorbate oxidation in aqueous humor. Curr Eye Res 1987; 6: 357-61.

9 Sparrow JM, Bron AJ, Brown NAP, Ayliffe W, Hill AR. The Oxford clinical cataract classification and grading system. Int Ophthalmol 1986; 9: 207-25.

10 Sasikala K. Personal communication, 1991.

11 Nath R, Srivastava SK, Singh K. Copper levels in human cataract lens. Ind $\mathcal{F}$ Exp Biol 1969; 7: 25-8.

12 Jain IS, Nath R. Zinc and copper levels in human senile cataractous lens. Proc Symp Recent Adv Biochem Cataracts cataractous

13 Shlopak TV. Chemistry of the crystalline lines in the normal and pathological states II. Chemical elements in the blood and crystalline lenses of patients with cataract. Ophthalmology 1962; 17: 247-51.

14 Murata T, Taura Y. Study of trace elements in the lens. Ophthalmology 1975; 28: 23-6.

15 Srivastava VK, Pandey DC. Copper in serum and lens of nuclear cataract. Symp Recent Adv Biochem Cataracts 1988: 77-85.

16 Srivastava VK, Srivastava SK, Afaqz Chaturvedi N, Garg M, Pandey DC. Photo-oxidative damage and coloration in Burscent cataract. Symp Recent Adv Biochem Cataracts 1988; 96-109.

17 Marraini G, Manguli R. Study of trace elements of cataract. CIBA Symp 1973; 79: 79-81.

18 Christine M, Laszloz B. Determination of copper concentration in blood plasma and in ocular and cerebrospinal fluids using graphite purnace. Anal Biochem 1983; 135: 186-92.

19 Arunsethi R, Nath N, Ahmed O, Sethi R. Comparative study of trace element levels in patients with mature senile cataracts. Proc Symp Recent Biochemic Cataracts. 1988; 77-85. 